\title{
USE OF SORGHUM STRAW (Sorghum bicolor) FOR SECOND GENERATION ETHANOL PRODUCTION: PRETREATMENT AND ENZYMATIC HYDROLYSIS
}

\author{
Wilton Soares Cardoso* \\ Instituto Federal do Espírito Santo, Campus Venda Nova do Imigrante, 29375-000 Venda Nova do Imigrante - ES, Brasil \\ Flávio Dessaune Tardin \\ Embrapa Milho e Sorgo, Rod MG 424 km 65, 35701-970 Sete Lagoas - MG, Brasil \\ Gabriella Peterlini Tavares, Paula Viana Queiroz, Samuel Sampaio Mota, Maria Catarina Megumi Kasuya e José Humberto \\ de Queiroz
}

Universidade Federal de Viçosa, 36570-000 Viçosa - MG, Brasil

Recebido em 5/6/12; aceito em 21/11/12; publicado na web em 4/4/13

\begin{abstract}
Agronomic biomass yields of forage sorghum BRS 655 presented similar results to other energy crops, producing 9 to 12.6 tons/ha (dry mass) of sorghum straw. The objective of this study was to evaluate the lignocellulosic part of this cultivar in terms of its potential in the different unit processes in the production of cellulosic ethanol, measuring the effects of pretreatment and enzymatic hydrolysis. Three types of pre-treatments for two reaction times were conducted to evaluate the characteristics of the pulp for subsequent saccharification. The pulp pretreated by alkali, and by acid followed by delignification, attained hydrolysis rates of over $90 \%$.
\end{abstract}

Keywords: biomass; lignocellulosic; energy crops.

\section{INTRODUCTION}

Lignocellulosic biomass (energy crops) and waste (forest, agricultural and urban) can provide renewable resources for the production of second generation biofuels. ${ }^{1}$ Given the possible viability in the medium term, innovative approaches for the production of bioethanol, especially by hydrolysis of cellulosic materials, has led to growing interest in energy crops. These include grasses for rapid growth and high biomass productivity, ${ }^{2}$ such as elephant grass (Pennisetum purpureum), ${ }^{3}$ used as forage in Brazil, switchgrass (Panicum virgatum), a species native to North America, ${ }^{2,4}$ besides the tall grass of the genus Miscanthus, of greatest interest in Europe as a source of biomass cellulose. ${ }^{5}$ Another potential crop for the production of second generation ethanol is sorghum. ${ }^{6}$

Sorghum [Sorghum bicolor (L.) Moench] is one of the main agricultural crops in the world scenario, and among the attributes that make it highly promising, is its broad genetic diversity and high tolerance to abiotic stresses such as drought and heat. In addition, sorghum requires less fertilizer than corn for high performance and can tolerate a wide range of conditions ${ }^{7}$ from heavy clay soils to sandy light soils, with $\mathrm{pH}$ ranging from 5.0 to $8.5,{ }^{8}$ as well as poorly drained soils. This makes the sorghum crop suitable for growing under ideal conditions as well as on marginal lands where other crops do not thrive. Unlike sugar cane, sorghum is grown from seed and has a much shorter growing season of around 120 to 130 days. This cereal is tolerant to dry periods during its cycle and produces economically lucrative crops of grains and green mass even under low rainfall or unstable conditions..$^{9,10}$

Sorghum is grown in Brazil predominantly for the production of grain and forage, although sweet sorghum is also used to produce alcohol. ${ }^{11}$ With cutting when sorghum reaches the maturation stage, use of only the leaves and stems that constitute the straw used in this work, can produce approximately $7.81 \mathrm{t}$ of dry matter/ha in around 110 days. $^{12,13}$ Considering two crop harvests a year, sorghum can yield about $15.62 \mathrm{t} / \mathrm{ha}$ of biomass which can be exploited to produce

*e-mail: wilton.cardoso@ifes.edu.br second generation ethanol. In addition, $15.6 \mathrm{t} / \mathrm{ha}$ of panicles with a high value for silage or as direct feed is produced.

Given the agronomic potential of new sorghum technologies, this study used forage sorghum straw of the BRS 655 variety for cellulosic ethanol production in order to evaluate the susceptibility of the material to different pretreatment and enzymatic hydrolysis.

\section{EXPERIMENTAL}

\section{Substrate}

This work was focused on the straw (stem and leaves) of sorghum BRS 655. The BRS 655 variety was developed by Embrapa Milho e Sorgo and cultivated in the city of Sete Lagoas, MG, Brazil. The straw was cut (harvested) within 120 days of planting, sun-dried and then coarsely ground in a mill. The ground material was stored in a dry place, shielded from light and moisture.

To conduct the pre-treatment, waste material was dried and crushed in a knife mill (model MR 340 - Metalurgica Roma) and ground to particles of 50 to 100 mesh size.

\section{Pretreatment}

The conditions of pre-treatments are described in Table 1. These pretreatment conditions were determined through several previous trials, whereby reaction times exceeding $30 \mathrm{~min}$ and or concentrations of acid or alkali $\left(\mathrm{H}_{2} \mathrm{SO}_{4}\right.$ or $\left.\mathrm{NaOH}\right)$ above $10 \%$ were not used because they were found to cause cellulose solubilization and decrease pulp yield. During the delignification process, the parameters time, baseline concentration and temperature of pretreatment acid were kept constant at $15 \mathrm{~min}, 50 \mathrm{~g} / \mathrm{L}$ and $120^{\circ} \mathrm{C}$, respectively.

The pretreatments were performed in an autoclave (model AV 80, Marconi). After each treatment the mixture was filtered, separating the hydrolyzed material (filtered) and pulp (retained material). The pulp was washed with distilled water until neutralization evidenced by the $\mathrm{pH}$ of the filtered liquid measured on a potentiometer (Hanna $\mathrm{pH} 21$ ). All assays were performed in triplicate. 
Table 1. Conditions used in the pretreatment of sorghum straw BRS 655

\begin{tabular}{lccc}
\hline & \multicolumn{2}{c}{ Pretreatments } \\
\cline { 2 - 4 } & Alkali $(\mathrm{NaOH})$ & Acid $\left(\mathrm{H}_{2} \mathrm{SO}_{4}\right)$ & Acid $\left(\mathrm{H}_{2} \mathrm{SO}_{4}\right)$ followed by delignification $(\mathrm{NaOH})$ \\
\hline Material (straw) & $10 \mathrm{~g}$ & $10 \mathrm{~g}$ & $10 \mathrm{~g}$ \\
Acidic or basic solution & $50 \mathrm{~g} / \mathrm{L}$ & $50 \mathrm{~g} / \mathrm{L}$ & $50 \mathrm{~g} / \mathrm{L}$ \\
Material/Solution $(\mathrm{g} / \mathrm{mL})$ & $1: 15$ & $1: 15$ & $1: 15$ \\
Reaction temperature & $120{ }^{\circ} \mathrm{C}$ & $120{ }^{\circ} \mathrm{C}$ & $120^{\circ} \mathrm{C}$ \\
Reaction time & 15 and $30 \mathrm{~min}$ & 15 and 30 min & 15 and 30 min \\
\hline
\end{tabular}

The pulp of each pretreatment was placed on Petri dishes and dried naturally at room temperature. After drying, the packed pulp was stored in a refrigerator. The pulp was tested to determine ash content, moisture and yield from its pre-treatment, adjusted for dry weight. The yield was calculated as the difference in weight of sorghum in natura (dry weight) and the pulp (dry weight) obtained from pretreatment divided by the weight of sorghum in natura (dry weight).

Control samples (untreated straw) were also analysed to determine moisture and ash. Hemicellulose, lignin and cellulose content was determined in pulp.

\section{Analysis of morphology}

The morphology of raw and pretreated sorghum straw was analysed by scanning electron microscopy (SEM). The SEM images of raw and pretreated straws were taken at different magnifications using LEO VP1430 equipment.

\section{Chemical analysis}

The cellulose contents were estimated by the difference between the levels of acid detergent fiber (ADF) and lignin and ash. Hemicellulose was determined by the difference between neutral detergent fiber (NDF) and ADF. The methodology of van Soest was used for ADF and NDF. ${ }^{14}$ The determination of lignin was done by the "Klason" method or by acid detergent lignin (ADL).

The determination of ash and moisture followed the protocols LAP 001 and LAP 004. ${ }^{15,16}$

\section{Enzymatic saccharification}

The enzyme complex Multifect GC (Genencor) was used for enzymatic hydrolysis of natural and pretreated sorghum. Other reagents were purchased from the companies Sigma Chemicals or Vetec Chemistry, all of analytical grade (PA).

Saccharification was performed on the resultant pulps obtained from each type of pretreatment and untreated straw sorghum. Saccharification was performed using the methodology recommended by the LAP 008 with adaptations. ${ }^{17}$ The production of glucose was monitored until $48 \mathrm{~h}$ of hydrolysis.

The enzyme load for total cellulase (FPase) and $\beta$-glycosidase, was $50 \mathrm{FPU} / \mathrm{g}$ and $54 \mathrm{U} / \mathrm{g}$ of cellulose from the material, respectively. The concentration of lignocellulosic material was $1 \%$, in sodium citrate $50 \mathrm{mM}$ buffer with $\mathrm{pH} 4.8$. Sodium azide $(0.02 \% \mathrm{w} / \mathrm{v})$ was used to inhibit microbiological growth during enzymatic hydrolysis.

\section{Analytical methods}

For the determination of total cellulase or Fpase activity (filter paper activity), the method proposed by Ghose ${ }^{18}$ with some modifications was followed. The concentrations of reducing sugars were determined by the 3,5-dinitrosalicylic (DNS) acid method described by Miller. ${ }^{19}$ A unit of total Cellulase (FPU - filter paper unit) was defined as the amount of enzyme which released the equivalent of 1 micromol of total reducing sugar in a minute, under assay conditions.

The activity of $\beta$-glycosidase (EC 3.2.1.21) was determined by incubating $1 \mathrm{~mL}$ of the substrate $\mathrm{p}$-nitrophenyl- $\beta$-D-glucoside 0.005 $\mathrm{M}$, in citrate buffer $0.05 \mathrm{M}, \mathrm{pH} 4.8$ with $100 \mu \mathrm{L}$ of the enzymatic complex for $15 \mathrm{~min}$ at $50{ }^{\circ} \mathrm{C}$. The reaction was stopped by adding 2.0 $\mathrm{mL}$ of sodium bicarbonate $1.0 \mathrm{M}$ and absorbance was measured at $410 \mathrm{~nm}$. The unit of enzymatic activity was expressed as the amount of enzyme capable of releasing 1 micromol of p-nitrophenol per minute, under assay conditions.

The saccharification experiments were conducted in Erlenmeyer $125 \mathrm{~mL}$ flasks on a shaker (Tecnal - TE 421) stirred at $120 \mathrm{rpm}$ and heated to $50{ }^{\circ} \mathrm{C}$. Samples of $0.5 \mathrm{~mL}$ were taken every $6 \mathrm{~h}$ until $12 \mathrm{~h}$, and then every $12 \mathrm{~h}$ until $48 \mathrm{~h}$, whereby each sample was heated at 100 ${ }^{\circ} \mathrm{C}$ for $5 \mathrm{~min}$ for inactivation of enzymes, centrifuged, and supernatant withdrawn for subsequent determination of glucose concentration.

The determination of glucose was based on the glucose oxidase reaction using the glucose monoesterase Bioclin AK 082 kit (Quibasa), where $10.0 \mu \mathrm{L}$ of sample and $1.0 \mathrm{~mL}$ of monoreagent glucose oxidase were placed in test tubes and kept at a steady temperature of $37^{\circ} \mathrm{C}$ for $15 \mathrm{~min}$ in a waterbath (Marconi MA-184). At the end of the reaction, absorbance was measured on a spectrophotometer (PG Instruments - T70 + UV/VIS) at $505 \mathrm{~nm}$. A standard curve of glucose (standard glucose Quibasa) was prepared.

Analysis of variance (ANOVA) and mean test (Tukey) were applied using the software SAEG. ${ }^{20}$

\section{RESULTS AND DISCUSSION}

The composition of lignocellulosic forage sorghum straw BRS 655 is shown in Table 2.

Table 2. Composition of lignocellulosic sorghum straw

\begin{tabular}{cc}
\hline Component & $\%$ dry basis \\
\hline Cellulose & 35.87 \\
Hemicellulose & 26.04 \\
Lignin & 7.52 \\
\hline
\end{tabular}

The cellulose $(35.87 \%)$, hemicellulose $(26.04 \%)$ and lignin $(7.52 \%)$ content of sorghum straw, shown in Table 2, was similar to elephant grass (Pennisetum purpureum), whose mean values observed were $32.50 \%$ for cellulose; $33.70 \%$ for hemicellulose and $5.40 \%$ for lignin. ${ }^{21}$ This sorghum variety has low lignin content, allowing milder and more economical pretreatments and better yields in saccharification and fermentation. ${ }^{22}$

For pulp yield of pretreatments (Table 3), no significant differences among types of pre-treatment $(p<0.05)$ were found, with 
Table 3. Lignocellulosic composition of sorghum BRS 655 straw in natura and pulps obtained after pretreatments

\begin{tabular}{|c|c|c|c|c|c|c|}
\hline Sample & $\begin{array}{l}\text { Reaction time } \\
(\min )\end{array}$ & $\begin{array}{l}\text { Yield }(\%) \\
\text { (dry basis) }\end{array}$ & $\begin{array}{c}\text { Cellulose } \\
(\mathrm{g} / 100 \mathrm{~g})(\text { dry basis })\end{array}$ & $\begin{array}{c}\text { Hemicellulose } \\
(\mathrm{g} / 100 \mathrm{~g})(\text { dry basis })\end{array}$ & $\begin{array}{c}\text { Lignin } \\
(\mathrm{g} / 100 \mathrm{~g})(\text { dry basis })\end{array}$ & $\begin{array}{c}\text { Ash } \\
(\mathrm{g} / 100 \mathrm{~g})(\text { dry basis })\end{array}$ \\
\hline Sorghum straw non-treated & & & $\begin{array}{l}35.87 \mathrm{D} \\
\pm 0.75 \\
\end{array}$ & $\begin{array}{c}26.04 \mathrm{~A} \\
\pm 0.50 \\
\end{array}$ & $\begin{array}{l}7.52 \mathrm{~B} \\
\pm 0.90 \\
\end{array}$ & $\begin{array}{l}2.18 \mathrm{~A} \\
\pm 0.12 \\
\end{array}$ \\
\hline \multirow{2}{*}{$\begin{array}{l}\text { Pretreatment acid } \\
\text { (Pulp acid) }\end{array}$} & 15 & $52.0 \mathrm{~A}$ & $\begin{array}{c}66.39 \mathrm{~A} \\
\pm 1.80\end{array}$ & $\begin{array}{l}1.25 \mathrm{C} \\
\pm 0.18\end{array}$ & $\begin{array}{l}30.00 \mathrm{~A} \\
\pm 1.55\end{array}$ & $\begin{array}{l}2.35 \mathrm{~A} \\
\pm 0.08\end{array}$ \\
\hline & 30 & $50.4 \mathrm{~A}$ & $\begin{array}{l}66.61 \mathrm{~A} \\
\pm 2.99\end{array}$ & $\begin{array}{l}0.87 \mathrm{C} \\
\pm 0.15\end{array}$ & $\begin{array}{c}30.24 \mathrm{~A} \\
\pm 2.84\end{array}$ & $\begin{array}{l}2.25 \mathrm{~A} \\
\pm 0,05\end{array}$ \\
\hline \multirow{2}{*}{$\begin{array}{l}\text { Pretreatment alkali } \\
\text { (Pulp alkali) }\end{array}$} & 15 & $37.9 \mathrm{~B}$ & $\begin{array}{l}88.44 \mathrm{~B} \\
\pm 1.63\end{array}$ & $\begin{array}{l}8.00 \mathrm{~B} \\
\pm 1.51\end{array}$ & $\begin{array}{l}0.86 \mathrm{C} \\
\pm 0.12\end{array}$ & $\begin{array}{l}2.70 \mathrm{~A} \\
\pm 0.07\end{array}$ \\
\hline & 30 & $38.3 \mathrm{~B}$ & $\begin{array}{l}87.89 \mathrm{~B} \\
\pm 0.38\end{array}$ & $\begin{array}{l}8.38 \mathrm{~B} \\
\pm 0.54\end{array}$ & $\begin{array}{l}0.87 \mathrm{C} \\
\pm 0.15\end{array}$ & $\begin{array}{l}2.86 \mathrm{~A} \\
\pm 0.14\end{array}$ \\
\hline \multirow{2}{*}{$\begin{array}{l}\text { Pretreatment acid with } \\
\text { delignification }\end{array}$} & 15 & $26.5 \mathrm{C}$ & $\begin{array}{l}96.54 \mathrm{C} \\
\pm 0.43\end{array}$ & $\begin{array}{l}1.24 \mathrm{C} \\
\pm 0.30\end{array}$ & $\begin{array}{l}1.57 \mathrm{C} \\
\pm 0.17\end{array}$ & $\begin{array}{l}0.65 \mathrm{~B} \\
\pm 0.05\end{array}$ \\
\hline & 30 & $25.6 \mathrm{C}$ & $\begin{array}{l}97.14 \mathrm{C} \\
\pm 0.33\end{array}$ & $\begin{array}{l}1.22 \mathrm{C} \\
\pm 0.18\end{array}$ & $\begin{array}{l}0.90 \mathrm{C} \\
\pm 0.10\end{array}$ & $\begin{array}{l}0.75 \mathrm{~B} \\
\pm 0.05\end{array}$ \\
\hline
\end{tabular}

Means followed by by the same letter (column) do not differ among themselves, the level of 5\% probability by Tukey test.

average of $51 \%, 38 \%$ and $26 \%$ for acidic, alkali and for acid followed by delignification processes, respectively. In relation to pretreatment with dilute acid, Silva ${ }^{23}$ obtained a similar yield of $57 \%$ when applying this pretreatment at a temperature of $120{ }^{\circ} \mathrm{C}$ for 10 min with $\mathrm{H}_{2} \mathrm{SO}_{4}$ $1 \%(\mathrm{w} / \mathrm{v})$, a solid-liquid ratio of 1:10 (m/v) and agitation of $100 \mathrm{rpm}$.

In general, for the different pretreatments, reaction time (15 or $30 \mathrm{~min}$ ) had no influence on the final composition of pulp (Table 3). However, the type of pre-treatment applied significantly affected all parameters analyzed.

The dilute acid treatment decreased the hemicellulose fraction by almost $100 \%$, there was however a concentration of lignin and cellulose in the pulps. Pretreatment acid is not effective for dissolving lignin, but can disorganize and increase susceptibility of cellulose to enzymatic hydrolysis. ${ }^{24}$

The alkali treatment removed about $90 \%$ of lignin and reduced the hemicellulose content by more than $70 \%$. The main effect of alkali pretreatment constitutes the removal of the lignin, promoting greater reactivity of the fiber.

Analyzing the yield data of each pre-treatment and the composition of the natural straw and lignocellulosic pulp obtained reveals that the pretreatments of acid, base, and of acid followed by delignification, caused cellulose losses of 5.5\%, 25.9 and $29.8 \%$, respectively. Silva ${ }^{23}$ observed a loss of $30 \%$ in pulp pre-delignification following acid treatment of corn stover, similar to the rate found in this work. Agricultural waste exhibits different behaviors regarding susceptibility of the cellulosic fraction to hydrolysis, reaching up to $50 \%$ cellulose degradation in experiments performed at temperatures in the application range of hydrothermal pretreatment of $150-230{ }^{\circ} \mathrm{C}$ approximately. ${ }^{25}$ It is noteworthy that the alkali pretreatment nor the subsequent delignification process does not cause degradation of cellulose, despite solubilization (loss) of $25.9 \%$ of the pulp for the alkali pretreatment.

The factors such as the solid/liquid ratio and reaction time employed were important for the control of degradation of the cellulosic fraction, avoiding the economic loss in the process of enzymatic conversion of cellulosic fraction into glucose for obtaining ethanol.

Vaccarino et al. ${ }^{26}$ studied the effects of pretreatments with $\mathrm{SO}_{2}$, $\mathrm{Na}_{2} \mathrm{CO}_{3}, \mathrm{NaOH}$ and enzymatic digestibility of grape pomace, and found that the highest degrading effects were obtained by pretreatment with $1 \% \mathrm{NaOH}$ at $120{ }^{\circ} \mathrm{C}$. Silverstein et al. ${ }^{27}$ studied the efficacy of pretreatments with sulfuric acid, sodium hydroxide, hydrogen peroxide and ozone for the enzymatic conversion of stems of cotton. The authors observed that pretreatment with sodium hydroxide resulted in the highest level of delignification $(65 \%$ with $2 \% \mathrm{NaOH}$ in 90 $\min$ at $121^{\circ} \mathrm{C}$ ).

The pretreatment of forage sorghum straw with acid followed by delignification obtained pulp with the highest content of cellulose and low concentration of lignin and hemicellulose.

The untreated material (image not shown) has a smooth, closed and intact surface. Corredor et al. ${ }^{28}$ in an evaluation of morphological characteristics of different varieties of forage sorghum cultivars using scanning microscopy, ascribed the characteristic of the smooth surface of the untreated material to the presence of waxes, hemicellulose, lignin and other binding materials.

The effects of pre-treatments on sorghum straw, analyzed by scanning electron microscopy, can be seen in Figure 1, quadrant 1, 2, 3, 4, 5 and 6 .

In the material pretreated by acid (quadrant 1 and 2 ) the disruption of the parenchyma and removal of the external surface exposing the internal structure, can be observed.
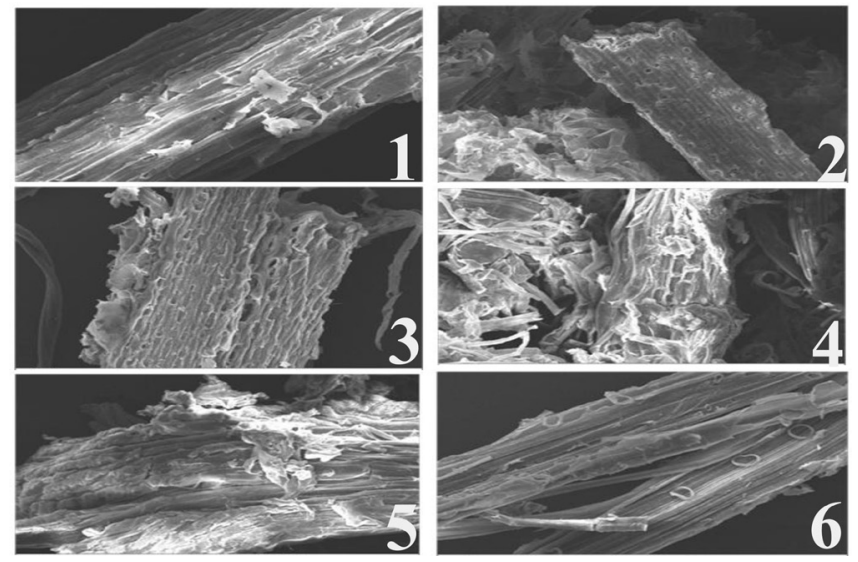

Figure 1. Microphotograph by scanning electron microscopy of sorghum straw: 1 - sorghum straw pretreated by dilute acid (5\%) for 15 min at $120^{\circ} \mathrm{C}$; 2 - sorghum straw pretreated by dilute acid (5\%) for 30 min at $120^{\circ} \mathrm{C} ; 3$ - sorghum straw pretreated by alkali (5\%) for 15 min at $120^{\circ} \mathrm{C} ; 4$ - sorghum straw pretreated by alkali (5\%) for 30 min at $120^{\circ} \mathrm{C} ; 5$ - sorghum straw pretreated by dilute acid $(5 \%)$ by $15 \mathrm{~min}$ at $120^{\circ} \mathrm{C}$, followed by delignification alkali (5\%) for 30 min at $120^{\circ} \mathrm{C}$; 6 - straw forage sorghum pretreated by dilute acid (5\%) by 30 min at $120^{\circ} \mathrm{C}$, followed by delignification alkali (5\%) for $30 \mathrm{~min}$ at $120^{\circ}$ C. Magnification: $632 x$ 

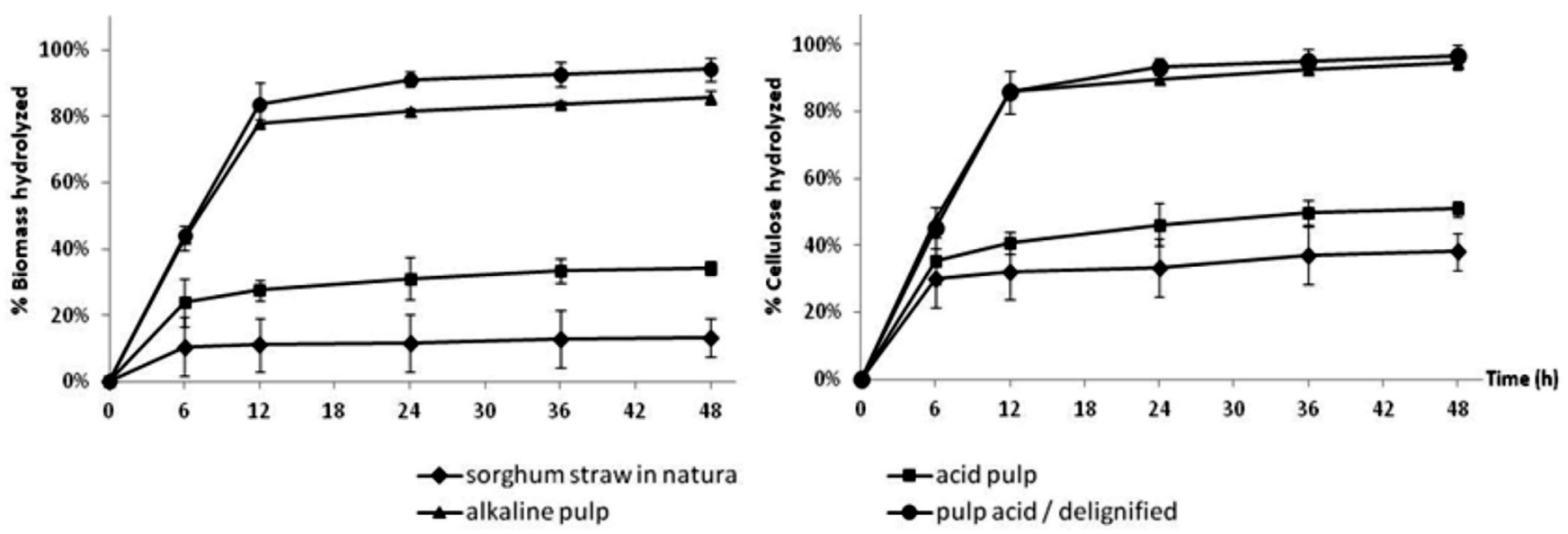

Figure 2. Saccharification of sorghum straw untreated and pulps obtained after application of pre-treatments, \% in relation to total biomass and in relation to $\%$ cellulose. Each point represents the mean of 3 replicate experiments \pm S.D (errors not shown were within the heights of the symbols)

For the alkali pretreatment (quadrant 3 and 4), it is evident that the sorghum straw had total removal of external surface and exposure of cellulose fibers.

The sorghum pretreated with acid followed by delignification (quadrant 5 and 6) exhibits individual cellulose fibers and the presence of annular rings. The annular rings are components of protoxylem cells of grasses, responsible for the elongation and stiffness of the vessel. The protoxylem is thickly lignified, ${ }^{29}$ and the presence of these rings shows efficiency in the removal of lignin from grasses.

These images confirm that the external and internal layers are the structures removed during the pretreatment, including part of the cellulose. The images corroborate the chemical analyses, which show large and visible components of solubilization increase their surface area, making the fibers more vulnerable to enzymatic attack.

The process of delignification of sugar cane straw pretreated with dilute acid resulted in pulp rich in individual cellulose fibers. ${ }^{30,31}$

The sorghum straw (untreated), and the pulps treated for $30 \mathrm{~min}$ with acid, base, and acid followed by delignification, were saccharified using the enzymatic complex Multifect CG. The results of these assays are shown in Figure 2.

The acid pulp and sorghum in natura had low hydrolysis levels, not reaching rates of $40 \%$. Pretreatment with dilute acid, although promoting an increase in enzymatic hydrolysis in comparison to natural material, did not produce a hydrolysis rate exceeding $40 \%$.

The rates of enzymatic hydrolyses of biomasses resulting from the pre-treatments of alkali and pulp acid/delignification were much higher than for the acid pretreatment, achieving levels close to $95 \%$ saccharified biomass for pulp acid/delignified versus around $85 \%$ for alkali pulp.

Concerning saccharification in relation to cellulose content, no significant difference was found for the pulps obtained from basic pretreatment and those from acid pretreatment followed by delignification.

These results can be explained partly by the presence of lignin in the untreated straw and acid pulp and its absence in the other pulps. The lignin delays the action of cellulases in several ways by forming a physical barrier, preventing the hydration of cellulose fiber, and binding non-specifically to proteins. ${ }^{32,33}$ The lignin content and its distribution are the factors responsible for the recalcitrance of lignocellulosic materials to enzymatic degradation, limiting the accessibility of the enzyme. ${ }^{3,34}$ This explains the improvement in rates of enzymatic hydrolysis of materials submitted to the processes of delignification.
The delignification of sugarcane straw pretreated with dilute acid favored the saccharification step, enabling the conversion rate to reach $84.5 \%,{ }^{30}$ a finding corroborated by the results obtained in this work.

The percentage of hydrolyzed cellulose showed the same value for both the alkali pulp and acid pulp followed by delignification (Figure 2). This result showed that the effect of lignin on saccharification is stronger than that of hemicellulose because, in saccharification of the alkali pulp, the levels of lignin were statistically identical to the delignified acid pulp, yet with about $8.00 \%$ hemicellulos reached the same level of hydrolysis as the delignified acid pulp with less than $1 \%$ hemicellulose. According to the literature, both hemicellulose and lignin form a physical barrier against enzymatic attack on cellulose, where lignin is a major factor limiting the enzymatic hydrolysis of cellulose. ${ }^{35,36}$ In this work, it was observed that the effect of hemicellulose on enzymatic hydrolysis is irrelevant compared to that of lignin.

Dien et al..$^{22}$ compared isogenic lines of sorghum with and without the bmr gene (related to the lignin content of the sorghum crop) and the efficiency of converting biomass into glucose. The authors found that those strains that had the bmr- 6 and bmr-12 genes were equally effective in reducing the lignin content, and that there was an additive reduction effect for the double mutant bmr-6/bmr-12. The sorghum samples were submitted to pretreatment with dilute acid before saccharification by cellulases. When compared to non-mutant lineages, glucose release was more efficient in mutants with increases of $27 \%$, $23 \%$ and $34 \%$ in terms of glucose released by mutants bmr- 6 , bmr- 12 and double mutant, respectively. Similar results were obtained when the pre-treatment was done with diluted bases. Thus, the authors concluded that reduced lignin content may have a positive impact on the efficiency of converting biomass into simple sugars.

The results obtained in this work corroborated those reported in the literature, evidencing that the removal of lignin and other components through pretreatment steps induced extensive change in the morphological structure of lignocellulosic biomass, as shown in Figure 1 (quadrants 3, 4, 5 and 6). These transformations make cellulose more accessible to contact with cellulolytic enzymes providing greater conversion of lignocellulosic biomass into glucose and consequently into ethanol.

\section{CONCLUSIONS}

Forage sorghum BRS 655 was shown to be a good alternative for production of second generation ethanol. This cultivar has great agricultural potential for biomass production, featuring a constitution 
with low lignin content. Sorghum was also found to be a material susceptible to pretreatments, whereby mild treatment can sufficiently reduce the hemicellulose and lignin, resulting in a pulp with high cellulose content.

The basic pre-treatment was sufficient to promote high enzymatic digestibility of sorghum straw.

\section{ACKNOWLEDGMENTS}

The authors acknowledge FAPEMIG and CNPq for financial support.

\section{REFERENCES}

1. Ramirez, R. Q. In Bioetanol de cana-de-açúcar. $P \& D$ para produtividade e sustentabilidade; Cortez, L. A. B., ed.; Blucker: Campinas, 2010.

2. Rocky, L.; Parrish, D. J.; CAB Reviews: Perspectives in Agric., Veterinary Sci., Nutrition and Natural Resour. 2009, 4, $\mathrm{n}^{\circ} 057$

3. del Río, J. C.; Prinsen, P.; Rencoret, J.; Nieto, L.; Barbero J. J.; Ralph, J.; Martínez, A. T.; Gutiérrez, A.; J. Agric. Food Chem. 2012, 60, 3619.

4. Parrish, D. J.; Fike, J. H.; Bransby, D. I.; Samson, R.; Establishing and managing switchgrass as an energy crop. Online. Forage and Grazinglands 2008. http://www.plantmanagementnetwork.org/pub/fg/ review/2008/energy/, accessed March 2013.

5. Heaton, E. A.; Dohleman, F. G.; Long, S. L.; Meeting US biofuel goals with less land: the potential of Miscanthus. Global Change Biology 2008, 14, 2000.

6. Damasceno, C. M. B.; Sousa, S. M.; Noda, R. W.; Parrella, R. A. C.; Schaffert, R. E.; Magalhães, J. V.; Documentos, Embrapa Milho e Sorgo, Sete Lagoas, 2010, 108.

7. Shoemaker, C. E.; Bransby, D.I. In Sustainable Alternative Fuel Feedstock Opportunities, Challenges and Roadmaps for Six U.S. Regions - Proceedings of the Sustainable Feedstocks for Advance Biofuels Workshop. Embassy Suites, Centennial Olympic Park - Atlanta, USA; Braun R.; Karlen, D.; Johnson, D., Eds., 2010. Chapter 9. http:// Www.swcs.org/documents/resources/Chapter_9__Shoemaker__ Sorghum_C07AF2168027B.pdf, accessed March 2013.

8. Smith, C. W.; Frederiksen, R. A.; Sorghum: Origin, history, technology, and production, John Wiley and Sons: New York, 2000.

9. Camacho, R.; Malavolta, E.; Gueireiro, J. A.; Camacho, T.; Scientia Agrícola 2002, 59, 771.

10. Neumann, M.; Restle, J.; Alves Filho, D. C.; Brondani, I. L.; Menezes, L. F. G.; Ciência Rural 2002, 32, 849.

11. Sawazaki, E. In Instruções agrícolas para as principais culturas econômicas; Falh, J. L., ed.; $6^{\text {a }}$ ed., IAC: Campinas, 1998, p. 44-49.

12. Rodrigues, J. A. S.; Santos, F. G.; Schaffert, R. E.; Ferreira, A. S.; Casela, C. R.; Tardin, F. D.; Circular técnica, Embrapa Milho e Sorgo, 2008,107.

13. Machado, F. S.; Dissertação de Mestrado, Universidade Federal de Minas Gerais, Brasil, 2009.
14. van Soest, P. J.; Robertson, J. B.; Lewis, B. A.; J. Anim. Sci. 1991, 74, 3583.

15. LAP 001 - Chemical Analysis and Testing Task Laboratory Analytical Procedure, https://engineering.purdue.edu/LORRE/research/LAP-001. pdf, accessed March 2013.

16. LAP 004 - Chemical Analysis and Testing Task Laboratory Analytical Procedure, https://engineering.purdue.edu/LORRE/research/LAP-004. pdf, accessed March 2013.

17. LAP 008 - Chemical Analysis and Testing Task Laboratory Analytical Procedure, https://engineering.purdue.edu/LORRE/research/LAP-008. pdf, accessed March 2013.

18. Ghose, T. K.; Pure Appl. Chem. 1986, 59, 257.

19. Miller, G. L.; Anal. Chem. 1959, 31, 426.

20. SAEG; Sistema para análise estatística e genética, V 9.1, Universidade Federal de Viçosa: Viçosa, Brasil, 2007.

21. Ribeiro, E. G.; Fontes, C. A. A.; Lima, M. L. P.; Martins, C. E.; Cóser, A. C.; Barros, E. E. L.; J. Anim. Prod. Sci. 2010, 67, 115.

22. Dien, B. S.; Sarath, G.; Pedersen, J. F.; Sattler, S. E.; Chen, H.; Funnellharris, D. L.; Nichols, N. N.; Cotta, M. A.; Bioenerg. Resour. 2009, 2 , 153.

23. Silva, V. F. N.; Dissertação de Mestrado, Universidade de São Paulo, Brasil, 2009.

24. Cardoso, W. S.; Santos, F. A.; Mota, C. M.; Tardin, F. D.; Resende, S. T.; Queiroz, J. H.; Revista Analytica 2012, 56, 64.

25. Garrote, G.; Dominguez, H.; Parajo, J. C.; Holz Als Roh-und Werkst. 1999, 57, 191.

26. Vaccarino, C.; Lo curto, R. B.; Tripodo, M. M.; Bellocco, E.; Laganfi, G.; Patan, R.; Biol. Waste. 1987, 20, 79.

27. Silverstein, R. A.; Chen, Y.; Sharma-shivappa, R. R.; Boyette, M. D.; Osborne, J.; Bioresour. Technol. 2007, 98, 3000.

28. Corredor, D. Y.; Salazar, J. M.; Hohn, K. L.; Bean, S.; Bean, B.; Wang, D.; Appl. Biochem. Biotechnol. 2009, 158, 164.

29. Kakosova, A. B.; Digonnet, C.; Goubet, F.; Ranocha, P.; Jauneau, A.; Pesquet, E.; Barbier, O.; Zhang, Z.; Capek, P.; Dupree, P.; Liskova, D.; Goffner, D.; Plant Physiol. 2006, 142, 696.

30. Oliveira, F. M. V.; Dissertação de Mestrado, Universidade de São Paulo, Brasil, 2010.

31. Rodrigues, R. S.; Dissertação de Mestrado, Universidade Federal de Viçosa, Brasil, 2009.

32. Vermerris, W.; Saballos, A.; Ejeta, G.; Mosier, N. S.; Ladisch, M. R.; Carpita, N. C.; Crop Sci. 2007, 47, S142.

33. Palonen, H.; Thomsen, A. B.; Tenkanen, M.; Schmidt, A. S.; Viikari, L.; Appl. Biochem. Biotechnol. 2004, 117, 1.

34. Sannigrahi, P.; Miller, S.; Ragauskas, A. J.; Carbohydr. Resour. 2010, 345, 965.

35. Berlin, A.; Gilkes, N.; Kurabi, A.; Bura, R.; Tu, M.; Kilburn, D.; Saddler, J.; Appl. Biochem. Biotechnol. 2005, 121, 163.

36. Taherzadeh, M. J.; Karimi, K.; BioResources 2007, 2, 707. 